\title{
Erratum to: Histo-biological comparative analysis of bilateral breast cancer
}

Bilal Baker • Basem Morcos • Faiez Daoud •

Maher Sughayer • Hisham Shabani •

Habeeb Salameh • Mahmoud Almasri

Published online: 8 November 2013

(C) Springer Science+Business Media New York 2013

Erratum to Med Oncol (2013) 30:711

DOI 10.1007/s12032-013-0711-8

Unfortunately, the name of author Maher Sughayer was misspelled in the online versions of this article. It is presented correctly here.

The online version of the original article can be found under doi:10.1007/s12032-013-0711-8.

B. Baker · B. Morcos · F. Daoud · H. Shabani · H. Salameh ·

M. Almasri $(\square)$

Department of Surgical Oncology, King Hussein Cancer Center,

KHCC, Queen Rania Al Abdullah Street, Amman 11941, Jordan

e-mail: malmasri@khcc.jo

B. Baker

e-mail: bilalbaker99@yahoo.com

M. Sughayer

Department of Pathology, King Hussein Cancer Center, KHCC,

Amman, Jordan 